\title{
WSPÓLNOTY SAMOPOMOCOWE DLA OSÓB UZALEŻNIONYCH I ICH RODZIN OGNIWEM WSPARCIA W OPIECE PIELĘGNIARSKIEJ I POŁOŻNICZEJ W POLSCE
}

\author{
MUTUAL-HELP GROUPS FOR ADDICTED PATIENTS AND THEIR FAMILIES AS A PARTNER \\ IN NURSING AND MIDWIFERY IN POLAND
}

\author{
Łukasz Kołodziej \\ Fundacja Instytut Zdrowia FIZ-LK, Prywatny Ośrodek Terapii Uzależnień TRATWA
}

https://orcid.org/0000-0002-9814-9158

DOI: https://doi.org/10.20883/pielpol.2020.6

\begin{abstract}
STRESZCZENIE
Uzależnienie od substancji psychoaktywnych oraz nałogowych czynności pociąga za sobą realne szkody zdrowotne. Dotknięte są nimi zarówno same osoby uzależnione, jak i również członkowie ich rodzin. Do zadań personelu pielęgniarskiego i położnych należy między innymi przeciwdziałanie szkodom zdrowotnym spowodowanym uzależnieniem. Grupy samopomocowe, takie jak np. wspólnota Anonimowych Alkoholików (AA) czy grupy rodzinne Anonimowych Alkoholików, zwane w skrócie Al-Anon, stanowią ważne uzupełnienie profesjonalnych form wsparcia osób uzależnionych i ich rodzin. W artykule zebrano zatem podstawowe informacje o grupach samopomocowych działających w Polsce. Oprócz tego podano przykłady współpracy pomiędzy profesjonalistami działającymi w obszarze przeciwdziałania uzależnieniom z grupami samopomocowymi. Spośród kilku wspólnot samopomocowych omówionych w tym artykule najlepiej udokumentowaną skutecznością oferowanych oddziaływań charakteryzuje się ruch AA oraz Al-Anon. W przypadku pozostałych wspólnot samopomocowych brakuje jednoznacznych wyników badań pokazujących skuteczność oferowanego wsparcia. Tym samym tylko udział w AA i Al-Anon można uznać za rekomendację pielęgniarską, mającą naukowe uzasadnienie.
\end{abstract}

SŁOWA KLUCZOWE: samopomoc, 12 kroków, uzależnienia, nałogowe czynności, rodziny osób uzależnionych.

\section{Wstęp}

Personel pielęgniarski spotyka się w swojej codziennej praktyce zawodowej z osobami uzależnionymi od substancji psychoaktywnych oraz cierpiącymi z powodu nałogowych czynności np. hazardu czy patologicznego korzystania z gier komputerowych. Negatywne skutki uzależnienia dotykają jednak nie tylko samej osoby chorej, ale również jej najbliższej rodziny $[1,2,3]$. Dotyczy to także płodów, których prawidłowy rozwój może być zagrożony przez uzależnienie od substancji psychoaktywnych matki

\begin{abstract}
Addiction to psychoactive substances as well as to compulsive behaviors can cause serious health problems. In fact, both addicts themselves and their family members are affected. Nursing staff and midwives are obligated to promote health and well-being among addicts and their families. Mutual-help groups, such as Alcoholics Anonymous community, play an important role in the public health and social rehabilitation of addicted patients and their families. Hence, the basic principles of the functioning of mutual-help communities operating in Poland are discussed. In addition, some examples of cooperation between mutual-support groups and health providers are given. Among several types of mutual-help communities discussed in this article, therapeutic effectiveness have been scientifically proven only in the case of Alcoholics Anonymous and the Al-Anon Family Group. In the case of other self-help communities mentioned in the article, the evidence showing positive outcome is scant. Therefore, participation only in AA and Al-Anon movement can be considered a nursing recommendation with scientific justification.
\end{abstract}

KEYWORDS: mutual help, 12 steps program, drug addiction, behavioural addiction, family members of addicted patient.

$[4,5,6]$. Stres wywołany nieprzewidywalnością i gwałtownością zachowania uzależnionego partnera matki, w tym również wszelkimi przejawami przemocy, także może skutkować u płodu negatywnymi konsekwencjami rozwojowymi [7, 8]. Położne, obok personelu pielęgniarskiego, mogą zatem odegrać ważną rolę w przeciwdziałaniu skutkom uzależnienia w rodzinie.

Obok przemocy domowej, nadmiernego zadłużenia i problemów bytowych, w rodzinach z problemem uzależnienia często rozwija się również patologiczna 
więź interpersonalna pomiędzy osobą uzależnioną a jej partnerem życiowym [9]. Nadmierne uwikłanie się w związek z kimś, kto przejawia destrukcyjne zachowania wobec swojego partnera życiowego określa się jako współuzależnienie [10, 11]. Stan ten cechuje się między innymi zaniedbywaniem własnych potrzeb, w tym także zdrowotnych, na rzecz koncentracji myśli, uczuć i zachowań wokół życia osoby uzależnionej [10, 11]. Współuzależnienie skutkuje zatem cierpieniem oraz narastającymi szkodami zdrowotnymi.

Negatywny wpływ używania środków odurzających i współuzależnienia w rodzinie nie ogranicza się jednak tylko do człowieka uzależnionego, bliskiej mu osoby i ewentualnie płodu w ciele matki. Dotyka również dzieci wychowujących się w rodzinach z problemem uzależnień [12]. W przypadku osób cierpiących w swoim dorosłym życiu z powodu konsekwencji alkoholizmu rodziców używa się pojęcia dorosłych dzieci alkoholika (dda) [13]. Kiedy system rodzinny był zaburzony z jakiegokolwiek innego powodu np. choroby psychicznej rodzica czy uzależnienia od narkotyków lub hazardu, mówi się o tzw. dorosłych dzieciach dysfunkcyjnych rodziców (dddr) [13, 14]. Podobnie jak współuzależnienie, tak również syndrom dda i dddr nie są uznane za odrębne jednostki nozologiczne [15]. Nie umniejsza to jednak cierpieniu osób przejawiających w życiu dorosłym cechy dda lub dddr. Zarówno u osób współuzależnionych, jak i u ich dzieci, mogą rozwijać się między innymi zaburzenia nastroju oraz odżywiania.

Do zadań personelu pielęgniarskiego i położnych należy między innymi promowanie zdrowego stylu życia, w tym także przeciwdziałanie negatywnym skutkom uzależnień [16]. Działania te można realizować między innymi poprzez udzielenie porad zdrowotnych, np. w formie tzw. krótkich interwencji wobec uzależnionych [17]. Kolejnym obszarem działania pielęgniarek i położnych jest motywowanie osób uzależnionych, współuzależnionych, dda oraz dddr do podjęcia psychoterapii [18]. Zadanie to nierozerwalnie wiąże się z informowaniem pacjentów o dostępnej ofercie terapeutycznej w pobliżu miejsca zamieszkania podopiecznego.

Uzupełnieniem profesjonalnych form terapii uzależnienia i jego skutków jest również udział osób chorych i ich rodzin w grupach samopomocowych, działających w oparciu o program 12 kroków/stopni (Tabela 1).

Najbardziej znanym przykładem wspólnot samopomocowych jest ruch AA i Al-Anon. Stały się one również pierwowzorem dla innych ruchów samopomocowych, tworzonych przez osoby uzależnione i ich rodziny.
W Polsce również działają wspólnoty tego typu. Zostały one przedstawione w postaci zbiorczego zestawienia w tabeli 2.

Tabela 1. 12 Kroków Anonimowych Alkoholików, które zostały zaadaptowane także przez inne wspólnoty samopomocowe do zdrowienia z różnych uzależnień i problemów z zachowaniem

Table 1. 12 Steps of Alcohol Anonymous which serves as a golden standard for various types of mutual support groups for addicted patients and their families

Krok 1. Przyznaliśmy, że jesteśmy bezsilni wobec alkoholu - że nasze życie stało się niekierowalne.

Step 1. We admitted we were powerless over alcohol - that our lives had become unmanageable.

Krok 2. Uwierzyliśmy, że Siła większa od nas samych może przywrócić nam zdrowy rozsądek.

Step 2. Came to believe that a Power greater than ourselves could restore us to sanity.

Krok 3. Podjęliśmy decyzję, aby powierzyć naszą wolę i nasze życie opiece Boga, tak jak Go rozumieliśmy.

Step 3. Made a decision to turn our will and our lives over to the care of God as we understood Him.

Krok 4. Zrobiliśmy wnikliwą i odważną osobistą inwenturę moralną. Step 4. Made a searching and fearless moral inventory of ourselves.

Krok 5. Wyznaliśmy Bogu, sobie i drugiemu człowiekowi istotę naszych błędów.

Step 5. Admitted to God, to ourselves and to another human being the exact nature of our wrongs.

Krok 6. Staliśmy się całkowicie gotowi, żeby Bóg usunął wszystkie te wady charakteru.

Step 6. Were entirely ready to have God remove all these defects of character.

Krok 7. Zwróciliśmy się do Niego w pokorze, aby usunął nasze braki. Step 7. Humbly asked Him to remove our shortcomings.

Krok 8. Zrobiliśmy listę wszystkich osób, które skrzywdziliśmy, i staliśmy się gotowi zadośćuczynić im wszystkim.

Step 8. Made a list of all persons we had harmed, and became willing to make amends to them all.

Krok 9. Zadośćuczyniliśmy osobiście wszystkim, wobec których było to możliwe, z wyjątkiem tych przypadków, gdy zraniłoby to ich lub innych. Step 9. Made direct amends to such people wherever possible, except when to do so would injure them or others.

Krok 10. Prowadziliśmy nadal osobistą inwenturę, z miejsca przyznając się do popełnianych błędów.

Step 10. Continued to take personal inventory and when we were wrong promptly admitted it.

Krok 11. Staraliśmy się przez modlitwę i medytację poprawiać nasz świadomy kontakt z Bogiem, tak jak Go rozumieliśmy, prosząc jedynie o poznanie Jego woli wobec nas oraz o siłę do jej spełnienia.

Step 11. Sought through prayer and meditation to improve our conscious contact with God as we understood Him, praying only for knowledge of His will for us and the power to carry that out.

Krok 12. Przebudzeni duchowo w rezultacie tych kroków staraliśmy się nieść to posłanie innym alkoholikom i stosować te zasady we wszystkich naszych poczynaniach.

Step 12. Having had a spiritual awakening as the result of these steps, we tried to carry this message to alcoholics and to practice these principles in all our affairs.

Źródło: opracowanie własne

Source: author's own analysis 
Tabela 2. Wspólnoty samopomocowe w Polsce, działające w oparciu o program 12 kroków, ukierunkowane na pomaganie pacjentom z różnymi formami uzależnień oraz problemami zdrowotnymi ich rodzinom Table 2. 12 steps groups operating in Poland for addicted patients and their families

\begin{tabular}{|c|c|c|}
\hline $\begin{array}{l}\text { Rodzaj uzależnienia } \\
\text { problemu zdrowotnego/ } \\
\text { Addictive behaviour } \\
\text { and health problem }\end{array}$ & $\begin{array}{l}\text { Grupy samopomoco- } \\
\text { we dla osób } \\
\text { uzależnionych/ } \\
\text { Mutual help groups } \\
\text { for addicted patients }\end{array}$ & $\begin{array}{l}\text { Grupy samopomocowe } \\
\text { dla rodzin osób } \\
\text { uzależnionych/ } \\
\text { Mutual groups for } \\
\text { concerned others }\end{array}$ \\
\hline $\begin{array}{l}\text { Uzależnienie od alkoholu/ } \\
\text { Alcohol addiction }\end{array}$ & $\begin{array}{l}\text { Anonimowi } \\
\text { Alkoholicy [19]/ } \\
\text { Alcoholics } \\
\text { Anonymous }\end{array}$ & $\begin{array}{c}\text { Grupy Rodzinne } \\
\text { Al-Anon [30]/ } \\
\text { Al-Anon Family Groups } \\
\text { Dorosłe Dzieci } \\
\text { Alkoholików [31]/ } \\
\text { Adult Children } \\
\text { of Alcoholics }\end{array}$ \\
\hline $\begin{array}{l}\text { Uzależnienie od narkotyków/ } \\
\text { Drug addiction }\end{array}$ & $\begin{array}{l}\text { Anonimowi } \\
\text { Narkomanii [20]/ } \\
\text { Narcotics } \\
\text { Anonymous }\end{array}$ & $\begin{array}{c}\text { Brak/ } \\
\text { Not operating }\end{array}$ \\
\hline $\begin{array}{l}\text { Uzależnienie od nikotyny/ } \\
\text { Nicotine addiction }\end{array}$ & $\begin{array}{c}\text { Anonimowi } \\
\text { Palacze [21]/ } \\
\text { Nicotine } \\
\text { Anonymous }\end{array}$ & $\begin{array}{c}\text { Brak/ } \\
\text { Not operating }\end{array}$ \\
\hline $\begin{array}{l}\text { Uzależnienie od hazardu/ } \\
\text { Pathological gambling }\end{array}$ & $\begin{array}{l}\text { Anonimowi } \\
\text { Hazardziści [22]/ } \\
\text { Gamblers } \\
\text { Anonymous }\end{array}$ & $\begin{array}{c}\text { Grupy Rodzinne } \\
\text { Haz-Anon [32]/ } \\
\text { Gam-Anon }\end{array}$ \\
\hline $\begin{array}{l}\text { Uzależnienie od seksu/ } \\
\text { Sex addiction }\end{array}$ & $\begin{array}{c}\text { Anonimowi } \\
\text { Seksoholicy [23]/ } \\
\text { Sexaholics } \\
\text { Anonymous } \\
\text { Anonimowi } \\
\text { Uzależnieni od Seksu } \\
\text { i Mitość [24]/ } \\
\text { Sex and Love Addicts } \\
\text { Anonymous }\end{array}$ & $\begin{array}{c}\text { Brak/ } \\
\text { Not operating } \\
\text { Brak/ } \\
\text { Not operating }\end{array}$ \\
\hline $\begin{array}{l}\text { Uzależnienie od gier } \\
\text { komputerowych/ } \\
\text { Computer addiction }\end{array}$ & $\begin{array}{c}\text { Anonimowi } \\
\text { Uzależnieni od Gier } \\
\text { Komputerowych [25]/ } \\
\text { (Anonimowi } \\
\text { Siecioholicy) } \\
\text { Computer Gaming } \\
\text { Addicts Anonymous }\end{array}$ & $\begin{array}{c}\text { Brak/ } \\
\text { Not operating }\end{array}$ \\
\hline $\begin{array}{l}\text { Zaburzenia odżywiania/ } \\
\text { Eating disorder }\end{array}$ & $\begin{array}{l}\text { Anonimowi } \\
\text { Jedzenioholicy [26]/ } \\
\text { Overeaters } \\
\text { Anonymous }\end{array}$ & $\begin{array}{c}\text { Brak/ } \\
\text { Not operating }\end{array}$ \\
\hline $\begin{array}{l}\text { Zaburzenia depresyjne/ } \\
\text { Depression disorder }\end{array}$ & $\begin{array}{l}\text { Anonimowi } \\
\text { Depresanci [27]/ } \\
\text { Depressed } \\
\text { Anonymous }\end{array}$ & $\begin{array}{c}\text { Brak/ } \\
\text { Not operating }\end{array}$ \\
\hline $\begin{array}{l}\text { Stosowanie przemocy } \\
\text { wobec innych/ } \\
\text { Family violence }\end{array}$ & $\begin{array}{c}\text { Anonimowi } \\
\text { Przemocowcy [28]/ } \\
\text { Violence Anonymous }\end{array}$ & $\begin{array}{c}\text { Brak/ } \\
\text { Not operating }\end{array}$ \\
\hline $\begin{array}{l}\text { Nadmierne zadłużenie/ } \\
\text { Over debt }\end{array}$ & $\begin{array}{c}\text { Anonimowi } \\
\text { Dłużnicy [29]/ } \\
\text { Debtors Anonymous }\end{array}$ & $\begin{array}{c}\text { Brak/ } \\
\text { Not operating }\end{array}$ \\
\hline
\end{tabular}

Źródło: opracowanie własne

Source: author's own analysis

Zachęcenie osoby potrzebującej wsparcia do udziału w grupie samopomocowej 12 kroków można zatem uznać za formę interwencji pielęgniarskiej i położniczej [18].
Tym samym celem tego artykułu jest przybliżenie czytelnikom zasad funkcjonowania grup tego typu w Polsce wraz z krótką charakterystyką czynników leczących działających w ruchu samopomocowym.

\section{Wspólnoty samopomocowe działające w oparciu o program 12 kroków w Polsce}

Najstarszą i największą grupą samopomocową dla osób uzależnionych od alkoholu jest wspólnota Anonimowych Alkoholików. Członkowie tego ruchu widzą możliwość leczenia uzależnienia od alkoholu w przestrzeganiu zasad życia zdefiniowanych w programie 12 Kroków AA [33]. To właśnie członkowie ruchu AA jako pierwsi podnieśli również kwestię konieczności pracy nad zdrowieniem ze skutków alkoholizmu całej rodziny, a nie tylko samej osoby uzależnionej [34]. W książce „Anonimowi Alkoholicy”, będącej fundamentem działania wspólnoty AA, znajdują się aż dwa rozdziały poświęcone zdrowieniu rodziny: „Do żon” oraz „Wizja rodziny przeobrażonej” [35].

Niemniej jednak z biegiem czasu okazało się, że program zdrowienia dla rodzin wymaga wzbogacenia o dodatkowe elementy. $W$ trzynaście lat po założeniu AA żony członków tej wspólnoty utworzyły wspólnotę grup rodzinnych Anonimowych Alkoholików, znaną pod nazwą Al-Anon, działającą w oparciu o program 12 stopni (w AA funkcjonuje program 12 Kroków) [36]. W skład ruchu Al-Anon wchodzą również grupy dedykowane dzieciom i młodzieży z rodzin z problemem alkoholowym (tzw. Alateen). Część grup Al-Anon samookreśla się jako grupy Al-Anon Dorosłe Dzieci. Grupy te nie powinny być mylone z ruchem samopomocowym dorosłych dzieci alkoholików.

We wspólnotach samopomocowych działających w oparciu o program 12 kroków najmniejszą a zarazem najważniejszą jednostką organizacyjną życia każdej wspólnoty jest grupa [37, 38]. Tworzą ją przynajmniej dwie osoby zbierające się w celu zdrowienia z uzależnienia lub jego skutków w rodzinie. Spotkania członków grup samopomocowych, w tym także AA i Al-Anon, noszą nazwę mityngów [37, 38]. Zebrania członków wspólnot samopomocowych przebiegają zgodnie z przyjętym przez grupę scenariuszem. Wyróżnia się kilka rodzajów mityngów. Na mityng otwarty może przyjść każda osoba zainteresowana zdrowieniem z uzależnienia i jego skutków w rodzinie, w tym także np. zainteresowane tematem pielęgniarki, pielęgniarze i położne. Mityngi zamknięte są dostępne wyłącznie dla osób deklarujących przynależność do określonej wspólnoty. Kolejnym rodzajem spotkania grupy samopomocowej jest tzw. mityng informacyjny na temat zasad funkcjonowania wspólnoty samopomocowej dla ludzi zainteresowanych tematem. Różnica pomiędzy mityngiem otwartym a in- 
formacyjnym polega głównie na tym, że w trakcie mityngów informacyjnych dużo mówi się na temat formalnych zasad działania wspólnoty [39].

W przypadku wspólnoty Al-Anon i AA mityngi informacyjne trwają około dwóch godzin i składają się z trzech części, tj. ze zwięzłego omówienia zasad działania danej wspólnoty, wypowiedzi członka ruchu samopomocowego na temat własnej drogi zdrowienia z uzależnienia/współuzależnienia, pytań ze strony personelu i zaproszonych gości do przedstawicieli ruchu samopomocowego [39].

Jak już wspomniano wcześniej, w Polsce struktury AA i Al-Anon działają na terenie całego kraju [40, 41]. W przypadku pozostałych wspólnot samopomocowych, wymienionych w tabeli $\mathbf{2}$, dostęp do mityngów tychże grup może być znacząco utrudniony ze względu na duże odległości geograficzne pomiędzy poszczególnymi grupami. Z przedstawicielami wspólnot samopomocowych działających w Polsce można jednak nawiązać kontakt telefoniczny, korespondencyjny lub za pomocą Internetu (adresy elektroniczne grup samopomocowych działających w kraju zebrano w tabeli 2). Tym samym ograniczenie w postaci niewielkiej liczby grup działających w różnych innych niż AA i Al-Anon ruchach samopomocowych jest zniwelowane.

\section{Czynniki leczące obecne w działaniach wspólnot samopomocowych}

Członkowie AA porównują udział w mityngach do korzystania z apteki oferującej lek na alkoholizm. W świetle paradygmatu medycyny opartej na dowodach naukowych, przytoczona metafora mityngu AA znajduje swoje potwierdzenie w wynikach badań. Posługując się metodami wnioskowano statystycznego oraz stosując metodologię prowadzenia badań porównawczych nad skutecznością interwencji psychoterapeutycznych wykazano, że udział osób uzależnionych w mityngach AA w sposób bardziej skuteczny pomaga utrzymywać trzeźwość w dłuższej perspektywie czasu aniżeli sama psychoedukacja na temat szkodliwości nadużywania alkoholu [42, 43, 44].

Wykazano również, że zaangażowanie pacjenta w realizacje programu 12 kroków i przestrzeganie zaleceń AA jest równie skuteczne co psychoterapia uzależnienia, prowadzona w nurcie poznawczo-behawioralnym. Wiadomo również, że udział w AA jest skutecznym sposobem na zainicjowanie u osoby uzależnionej motywacji do utrzymywania abstynencji w dłuższej perspektywie czasu. Innymi słowy, udział w AA pomaga rozpocząć trzeźwienie, a nie tylko przyspiesza i podtrzymuje proces zdrowienia z uzależnienia od alkoholu u osób, które i tak zdrowiałyby z alkoholizmu poza AA [45].
Udział w Al-Anon zalecany jest osobom, które borykają się z problemami zdrowotnymi, w tym także psychicznymi, z powodu alkoholizmu kogoś bliskiego w rodzinie. Tym samym istnieje konieczność prowadzenia badań naukowych nad skutecznością wsparcia udzielanego w Al-Anon. Pozytywny wpływ udziału w Al-Anon przejawia się głównie w trzech obszarach życia członków wspólnoty. Poprawie ulega subiektywnie postrzegana jakość życia osób będących w relacji z kimś uzależnionym. Wśród uczestników wspólnoty wzrasta również zadowolenie z bieżącego stanu relacji interpersonalnej z osobą uzależnioną. Przemianie pozytywnej podlega również rodzaj stylu radzenia sobie z problemami, jakie niesie ze sobą życie z kimś uzależnionym [46, 47]. Wśród uczestników Al-Anon obserwuje się zmianę stylu radzenia sobie ze stresem z unikowego na styl skoncentrowany na zadaniu. Skutkuje to między innymi wzrostem samooceny wśród uczestników Al-Anon i poprawą wiary w swoją skuteczność [46].

Niemniej jednak, kiedy porównano dwie grupy uczestników Al-Anon, tj. nowicjuszy (osoby zaangażowane w Al-Anon nie dłużej niż sześć miesięcy) z weteranami wspólnoty (członkowie Al-Anon będący we wspólnocie dłużej niż sześć miesięcy), nie wykazano znaczącej poprawy zdrowia psychicznego uczestników ruchu Al-Anon. U około 40\% badanych zdiagnozowano depresję oraz stany lękowe. Pomimo tego pozytywnym aspektem udziału w Al-Anon było zmniejszenie spożywania alkoholu przez uczestników Al-Anon [32]. Tym samym udział w Al-Anon można potraktować jako oddziaływanie profilaktyczne wobec osób zagrożonych sięganiem po alkohol i leki. Wykazano bowiem, że osoby będące w związku z alkoholikiem znacząco częściej sięgają po leki z przepisu lekarza, w tym także z grupy benzodiazepin [46].

Na podstawie badań nad uczestnikami ruchu AlAnon w Stanach Zjednoczonych wiadomo, że zaangażowanie w ten ruch przynosi wymierne efekty po około sześciu miesiącach, przy regularnym uczęszczaniu na przynajmniej jeden mityng w tygodniu [48]. Z badań naukowych nad ruchem AA wynika, że uczestniczenie w mityngu przynajmniej raz w tygodniu sprzyja utrzymywaniu abstynencji w dłuższej perspektywie czasu [43]. Jest to też minimalna liczba mityngów w tygodniu, która pomaga osobom uzależnionym podtrzymać wypracowaną wcześniej w trakcie terapii uzależnienia zdolność utrzymywania abstynencji [43]. Wykazano również celowość kierowania osób uzależnionych od alkoholu na mityngi nawet przed podjęciem terapii uzależnienia [43]. Istnieją również przesłanki naukowe, wskazujące na celowość kierowania osób uzależnionych od innych rzeczy niż alkohol również na mityngi AA [49]. 
W przypadku AA i Al-Anon postuluje się istnienie zbioru czynników leczących, które działając łącznie, warunkują zdrowienie z uzależnienia od alkoholu j jego skutków w rodzinach. W myśl hipotezy prof. Mossa i jego grupy badawczej, za zdrowienie w AA i Al-Anon odpowiadają procesy społeczne, które prowadzą do zmiany zachowania uczestników grup samopomocowych $[43,47,50]$. Do procesów tych zaliczamy między innymi:

1. wsparcie i przywiązanie pomiędzy uczestnikami wspólnoty samopomocowej;

2. ukierunkowanie na osiąganie wspólnego celu grupy, tj. zdrowienia z uzależnienia od alkoholu i jego skutków;

3. ustrukturyzowanie działania w oparciu o wspólny dla wszystkich członków program zdrowienia;

4. ustalenie wspólnych norm grupowych i oczekiwań wobec członków wspólnoty;

5. modulowanie ról społecznych wśród członków ruchu samopomocowego;

6. zaangażowanie członków wspólnoty w działania przynoszące subiektywne odczucie przyjemności, poczucie przydatności społecznej i sprawstwa.

W przypadku pozostałych wspólnot samopomocowych wymienionych w tabeli 2 brakuje przekonywujących dowodów naukowych na temat skuteczność oferowanej pomocy. Jak dotąd nikt nie wykazał też szkodliwego wpływu tych wspólnot samopomocowych na osoby korzystające z ich wsparcia. Można również przypuszczać, że w grupach samopomocowych innych niż AA i Al-Anon wymienione wyżej prozdrowotne procesy społeczne również występują i mogą przynieść korzyść uczestnikom ruchów samopomocowych [51, 51]. Niemniej jednak wciąż jest to hipoteza, która wymaga dalszej weryfikacji.

\section{Współpraca z AA i Al-Anon przy promocji zdrowia}

Współpraca ruchów samopomocowych z profesjonalistami zajmującymi się problematyką uzależnień odbywa się w oparciu o reguły zebrane w postaci 12 Tradycji. Stanowią one zbiór zasad regulujących różne formalne aspekty funkcjonowania wspólnot samopomocowych. W przypadku ruchu AA współpraca tej grupy samopomocowej z różnego typu profesjonalistami odbywa się właśnie w ramach 5. tradycji AA [33]. Brzmi ona następująco: „Każda grupa ma jeden główny cel: nieść posłanie alkoholikowi, który wciąż jeszcze cierpi”. 5. tradycja wspólnoty Al-Anon sugeruje członkom grup nie tylko pomoc rodzinom osób uzależnionych, ale również samym osobom uzależnionym, mówiąc „o rozumieniu i dodawaniu otuchy naszym pijącym krewnym" [53].
Przedstawiciele wspólnot samopomocowych bardzo chętnie przychodzą zatem na zaproszenie np. służb społecznych zaangażowanych w przeciwdziałanie skutkom uzależnień w społecznościach lokalnych. Promotorzy zdrowia, pielęgniarze i pielęgniarki mogą więc skorzystać z bezpłatnej współpracy z przedstawicielami wspólnot samopomocowych przy organizowaniu prelekcji o tematyce związanej z przeciwdziałaniem skutkom uzależnień. Położne mogą też wzbogacić ofertę szkół rodzenia o spotkania informacyjne z przedstawicielami ruchu AA i Al-Anon.

W myśl 6. i 10. tradycji AA i Al-Anon wspólnoty te nie wypowiadają się na temat profesjonalnych systemów terapeutycznych, religii, polityki oraz spraw związanych z szeroko pojętą ochroną zdrowia osób uzależnionych i ich rodzin [53]. Tym samym podejmując współpracę z AA i Al-Anon, mamy małe ryzyko uwikłania się w niechciane afiliacje religijne, polityczne lub ruchy podważające celowość leczenia.

W ramach struktur wspólnot samopomocowych AA i Al-Anon działają wyspecjalizowane grupy zadaniowe opracowujące ujednolicone materiały informacyjne oraz książki o tematyce zdrowienia z uzależnienia i jego skutków. W Polsce dostępne są następujące pozycje wydawnicze:

Lista tytułów książek aprobowanych przez Konferencję Ogólną Służb Światowych AA przetłumaczonych na język polski:

- Anonimowi Alkoholicy (ang. Alcoholics Anonymous) (wyd. II), Fundacja Biuro Służby Krajowej Anonimowych Alkoholików w Polsce, Warszawa 2015.

- Dwanaście Kroków i Dwanaście Tradycji (ang. Twelve Steps and Twelve Traditions), Fundacja Biuro Służby Krajowej Anonimowych Alkoholików w Polsce, Warszawa 2013.

- Życie w trzeźwości (ang. Living sober), Fundacja Biuro Służby Krajowej Anonimowych Alkoholików w Polsce, Warszawa 2000.

- Anonimowi Alkoholicy wkraczają w dojrzałość (ang. Alcoholics Anonymous comes of age), Fundacja Biuro Służby Krajowej Anonimowych Alkoholików w Polsce, Warszawa 2010.

- Przekaż dalej. Opowieść o Billu Wilsonie i o tym, jak posłanie AA ogarnęło cały świat (ang. Pass it on. The story of Bill Wilson and how AA message reached the world), Fundacja Biuro Służby Krajowej Anonimowych Alkoholików w Polsce, Warszawa 2013.

- Jak to widzi Bill. AA jako droga życia. Wybór pism współzałożyciela AA (ang. As Bill Sees it. The AA Way of Life. Selected writings of AA co-founder), Fundacja Biuro Służby Krajowej 
Anonimowych Alkoholików w Polsce, Warszawa 2015.

- Doktor Bob i dobrzy weterani (ang. Dr. Bob and the Good Oldtimers), Fundacja Biuro Służby Krajowej Anonimowych Alkoholików w Polsce, Warszawa 2009.

- Więzień do więźnia (ang. AA in prison. Inmate to Inmate), Fundacja Biuro Służby Krajowej Anonimowych Alkoholików w Polsce, Warszawa 2009.

- The Best of Bill, Fundacja Biuro Służby Krajowej Anonimowych Alkoholików w Polsce, Warszawa 2010.

- Codzienne refleksje (ang. Daily reflections), Fundacja Biuro Służby Krajowej Anonimowych Alkoholików w Polsce, Warszawa 2015.

- Historia AA w Polsce (t. 1) (ang. History of AA in Poland), Fundacja Biuro Służby Krajowej Anonimowych Alkoholików w Polsce, Warszawa 2015.

- Uwierzyliśmy (ang. Came to Believe), Fundacja Biuro Służby Krajowej Anonimowych Alkoholików w Polsce, Warszawa 2001.

Lista tytułów książek i broszur informacyjnych aprobowanych przez Konferencję Służby Światowej Grup Rodzinnych Al-Anon, przetłumaczone na język polski:

- Dwanaście Stopni i Dwanaście Tradycji dla AlAnon (ang. Al-Anon's Twelve Steps and Twelve Traditions), (wyd. IV), Stowarzyszenie Służb Grup Rodzinnych Al-Anon, Poznań 2009.

- Dzień po dniu w Al-Anon (ang. One day at Time in Al-Anon), (wyd. VII), Stowarzyszenie Służb Grup Rodzinnych Al-Anon, Poznań 2010.

- Odwaga do zmian. Dzień po dniu w Al-Anon II (ang. Courage to Change. One day at one time in Al-Anon), (wyd. I), Stowarzyszenie Służb Grup Rodzinnych Al-Anon, Poznań 2015.

- Od przetrwania do zdrowienia. Dorastanie w domu z problemem alkoholowym (ang. From survival to recovery: Growing up in an Alcoholic Home), (wyd. I), Stowarzyszenie Służb Grup Rodzinnych Al-Anon, Poznań 2014.

- Problemy w małżeństwie z alkoholikiem (ang. The Dilema of the Alcoholic marriage), (wyd. III), Stowarzyszenie Służb Grup Rodzinnych AlAnon, Poznań 2007.

- Wskazówki do pracy nad sobą według Stopnia IV Al-Anon (ang. Blueprint for progres) (wydanie rozszerzone), (wyd. I), Stowarzyszenie Służb Grup Rodzinnych Al-Anon, Poznań 2017.
- Dwanaście Stopni i Dwanaście Tradycji dla Alateen (ang. Alateen's Twelve steps and Twelve Traditions), (wyd. Il poprawione), Stowarzyszenie Służb Grup Rodzinnych Al-Anon, Poznań 2014.

- $\quad$ Alateen - dzień po dniu (ang. Alateen - a day at one time), (wyd. Il poprawione), Stowarzyszenie Służb Grup Rodzinnych Al-Anon, Poznań 2012.

- Alateen nadzieja dla dzieci alkoholików (ang. Alateen. Hope for Children of Alcoholics), (wyd. III poprawione), Stowarzyszenie Służb Grup Rodzinnych Al-Anon, Poznań 2012.

- $\quad$ Praca Grup Al-Anon i Alateen (ang. Al-Anon and Alateen groups at work). (wyd. III), Stowarzyszenie Służb Grup Rodzinnych Al-Anon, Poznań 2008.

W przypadku wspólnoty AA za zgodność publikowanych materiałów i książek z przesłaniem wspólnoty odpowiadają służby światowe AA [33]. W Al-Anon odpowiedzialność za aprobatę materiałów źródłowych odpowiada Konferencja Służb Światowych Al-Anon. Pozostałe wspólnoty samopomocowe również opracowują i publikują książki oraz broszury informacyjne, których treść wymaga aprobaty przez wyspecjalizowane służby światowe tychże organizacji. Tym samym literatura publikowana przez wspólnoty samopomocowe stanowi wiarygodne źródło informacji na temat zdrowienia z uzależnienia i jego skutków. Można więc oferować pacjentom uzależnionym i ich rodzinom czytanie literatury 12 kroków.

Książki oraz materiały informacyjne publikowane są z pominięciem imion i nazwisk autorów. Wynika to z anonimowości członków wspólnot samopomocowych oraz przekonania o konieczności prezentowania zbiorowego doświadczenia w zdrowieniu ze skutków uzależnienia i jego skutków, a nie poglądów indywidualnych osób. Pozytywny wpływ literatury grup działających w oparciu o program 12 kroków na poprawę kondycji psychicznej uczestników tego ruchu jest przykładem wykorzystania elementów biblioterapii oraz elementów terapii behawioralno-poznawczej przez nieprofesjonalistów [33]. Materiały drukowane AA i Al-Anon można więc bezpiecznie polecać pacjentom i ich rodzinom w ramach promocji zdrowia.

Oprócz książek wspólnoty samopomocowe publikują i kolportują również różnego typu broszury informacyjne oraz logotypy informujące o działalności wspólnot w danej miejscowości (Rycina 1). 
A

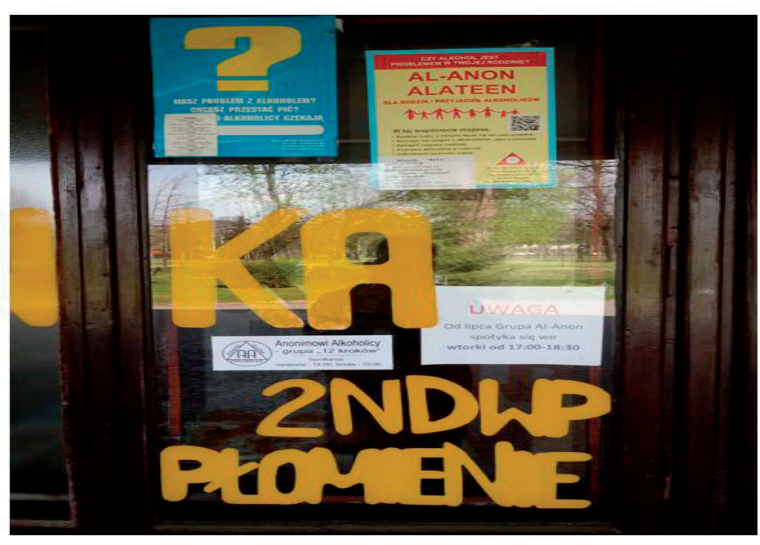

B

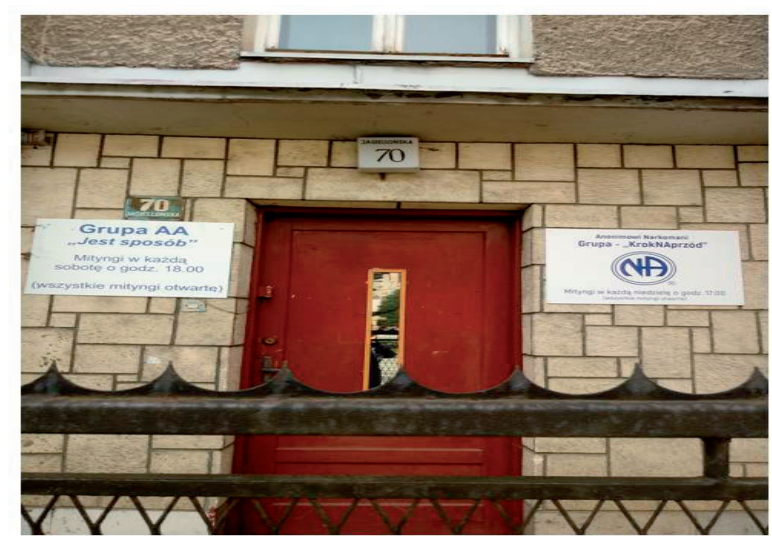

Rycina 1. Plakaty i logotypy wybranych wspólnot samopomocowych działających w Nowym Sączu, widoczne z ulicy dla przechodniów, informujące o miejscu i czasie mityngów.

A) plakaty AA i Al-Anon; B) informacja o miejscu i czasie mityngów AA oraz wspólnoty Anonimowych Narkomanów

Figure 1. Posters and logo types of mutual help groups present in Nowy Sacz, Poland keeping pedestrians informed about meetings held in that buildings.

A) posters of Alcohol Anonymous and Al-Anon family groups; B) logo types of Alcohol Anonymous and Narcotic Anonymous group

Źródło: opracowanie własne

Source: author's own analysis

Pomaga to osobom zainteresowanym uzyskaniem pomocy $w$ dotarciu na mitingi. Niektóre grupy działające w ramach wspólnot samopomocowych (np. AA, Al-Anon, AN) umieszczają również za zgodą dyrekcji podmiotów leczniczych, materiały informacyjne tych wspólnot w poczekalniach i innych miejscach dostępnych dla pacjentów (Rycina 2).

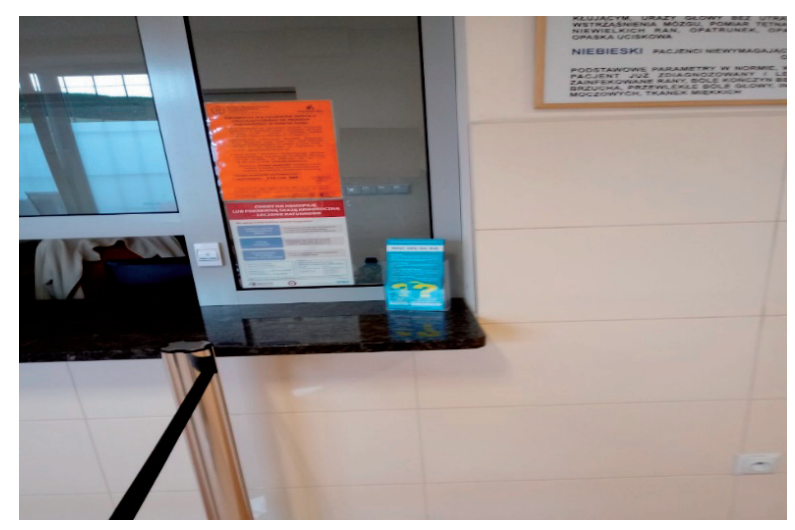

Rycina 2. Współpraca lokalnego szpitala z ruchem AA

Materiały informujące o działalności grup Anonimowych Alkoholików na Sądecczyźnie umieszczone za zgodą Dyrekcji Szpitala Specjalistycznego im. Jędrzeja Śniadeckiego w recepcji Szpitalnego Oddziału Ratunkowego.

Figure 2. Collaboration between local hospital and AA movement Leaflets of Alcoholic Anonymous groups, operating in the region of Nowy Sacz, Poland, placed in the Emergency Unit of Jedrzej Sniadecki Hospital upon approval provided by the chief executive of hospital.

Źródło: opracowanie własne

Source: author's own analysis
W ten sposób osoby zainteresowane podjęciem terapii uzależnienia i współuzależnienia mogą anonimowo i bezpłatnie dowiedzieć się o mityngach określonej wspólnoty w pobliżu miejsca zamieszkania. Poprzez zgodę na umieszczenie materiałów informacyjnych w swoich budynkach podmioty lecznicze zyskują możliwość udokumentowania swoich działań na rzecz realizacji gminnych programów przeciwdziałania uzależnieniom. Można zatem wykorzystać współpracę z ruchami samopomocowymi do zintensyfikowania współdziałania z samorządem lokalnym przy realizacji zadań promujących zdrowy styl życia związanych z przeciwdziałaniem skutkom uzależnień i [54].

\section{Podsumowanie}

W świetle dostępnych wyników badań naukowych nad skutecznością oddziaływań oferowanych przez AA i AlAnon można rekomendować pacjentom udział $w$ tych wspólnotach. Przy obecnym stanie wiedzy nie można jednak udzielić jednoznacznie pozytywnej rekomendacji odnośnie formułowania zaleceń pielęgniarskich w zakresie kierowania pacjentów i ich rodzin do wspólnot samopomocowych innych niż AA i Al-Anon.

Czytanie literatury aprobowanej przez wspólnoty samopomocowe, zwłaszcza AA i Al-Anon, może również stanowić zalecenie pielęgniarskie $w$ opiece nad osobami uzależnionymi lub cierpiącymi z powodu problemu uzależnienia w rodzinie. Współpraca personelu pielęgniarskiego i położnych z grupami samopomoco- 
wymi przy organizowaniu spotkań promujących życie wolne od uzależnień może pomóc przekazać pacjentom rzetelną wiedzę na temat możliwości zdrowienia z uzależnienia i jego skutków.

\section{Piśmiennictwo}

1. Kacprzak A. Międzypokoleniowa transmisja alkoholizmu (na podstawie narracji „trzeźwiejących” alkoholików). Acta Universitatis Lodziensis. Folia Sociologica. 2011; 38: 73-89.

2. Grzegorzewska I, Cierpiałkowska L. Pozytywna i negatywna adaptacja dzieci i młodzieży rodziców uzależnionych od alkoholu. Alcoholism and Drug Addiction. 2015; 28(4): 221-233.

3. Mikołajczyk M. Poradnictwo i pomoc dla osób współuzależnionych. W: Poradnictwo w dyskursie interdyscyplinarnym. red. naukowa Szluz B, Szluz A. Wydawnictwo Uniwersytetu Rzeszowskiego; Rzeszów 2018: 63-83.

4. Bernfeld B, Mazurkiewicz J. „Za młody, by pić”. Naruszenie prawa do życia lub zdrowia dziecka przez pijące alkohol kobiety ciężarne. Wrocław 2016: 1-36.

5. Kociszewka-Najman B i inni. Zaburzenia rozwoju płodu spowodowane spożywaniem alkoholu przez kobietę w ciąży. Karmienie piersią a alkohol. Ginekologia i Perinatologia Praktyczna 2017. 2(4): 176-190.

6. Vassoler FM, Byrnes EM, Pierce RC. The impact of exposure to addictive drugs on future generations: Physiological and behavioral effects. Neuropharmacology. 2014; 1(76) Pt B: 269-75.

7. Graignic-Philippe i inni. Effects of prenatal stress on fetal and child development: A critical literature review. Neurosci. Biobehav. Rev. 2014; 6(43): 137-162.

8. Pawłowska-Muc AK i inni. Problem przemocy domowej w praktyce zawodowej pielęgniarek i położnych. Journal of Education, Health and Sport. 2017; 7( 4): 38-50.

9. Ryś M. Rodzinne uwarunkowania psychospołeczne funkcjonowania Dorosłych Dzieci Alkoholików. PWN: 2007: 43-54.

10. Załuska M. Kossowska-Lubowicka A. Współuzależnienie i zespół stresu pourazowego w rodzinie alkoholowej. Studia nad Rodziną UKSW. 2009; 13 1-2 (24-25): 311-322.

11. Ciosek M. Sekretny świat rodziny z problemem alkoholowym. Studia Gdańskie. Wizje i Rzeczywistość; 2011; VIII: 270-282.

12. Chrzan-Dętkoś M, Walczak T. Uzależnieni rodzice - narażone dziecko. Zakłócenia w funkcjonowaniu uzależnionych matek w relacji z niemowlętami oraz możliwość skutecznej pomocy. Psychoterapia. 2017; 2(181): 21-36.

13. Ryś M. Rodzinne uwarunkowania psychospołeczne funkcjonowania Dorosłych Dzieci Alkoholików, PWN: 2007: 113-114.

14. Margasiński A. Pułapki diagnozy psychologicznej na przykładzie efektu Barnuma i tzw. syndromu dorosłych dzieci z rodzin dysfunkcyjnych. Studia Psychologica: Theoria et praxis. 2013; 13(1): 85-99.

15. Hędzelek M. Choroba współuzależnienia od alkoholu - diagnoza, konsekwencje, leczenie. Probl Hig Epidemiol. 2009; 93: 309-315.

16. Mełech B i inni. Rola pielęgniarki w diagnozowaniu i leczeniu chorych uzależnionych od alkoholu. W: Rola pielęgniarki w procesie pielęgnowania pacjentów w zależności od jednostki chorobowej. Zeszyty Naukowe. Łomża: Wydawnictwo Wyższej Szkoły Agrobiznesu w Łomży. 2013; 49: 71-77.

17. Bradley KA i inni. Alcohol-Related Nurse Care Management in Primary Care: A Randomized Clinical Trial. JAMA Intern Med. 2018; 178(5): 613-621.
18. Ziółkowski M i inni. Zaburzenia spowodowane przyjmowaniem substancji psychoaktywnych. W: Górska K. Jaracz K. Rybakowski J (red.). Pielęgniarstwo psychiatryczne. Warszawa: PZWL; 2016: 263-291.

19. http://www.anonimowi-alkoholicy.org.pl [dostęp; access: 23.04.2019 r.].

20. https://www.anonimowinarkomani.org [dostęp; access: 23.04.2019 r.].

21. http://anonimowipalacze.pl [dostęp; access: 23.04 .2019 r.].

22. http://www.anonimowihazardzisci.org [dostęp; access: 23.04.2019 r.].

23. https://sa.org.pl [dostęp; access: 23.04.2019 r.].

24. http://www.slaa.pl [dostęp; access: 23.04.2019 r.].

25. http://anonimowi-siecioholicy.org [dostęp; access: 23.04.2019 r.].

26. https://anonimowijedzenioholicy.org [dostęp; access: 23.04.2019 r.].

27. http://adepresanci.manifo.com [dostęp; access: 23.04.2019 r.].

28. https://anonimowiprzemocowcy.pl [dostęp; access: 23.04.2019 r.].

29. http://programwsparcia.com/wspolnota-dluznikowanonimowych [dostęp; access: 23.04.2019 r.]

30. http://al-anon.org.pl [dostęp; access: 23.04.2019 r.].

31. http://www.dda.org.pl [dostęp; access: 23.04 .2019 r.].

32. http://www.anonimowihazardzisci.org/wsp\%C3\%B3lnotahaz-anon.html [dostęp; access: 23.04.2019 r.].

33. Kołodziej $Ł$. Wybrane aspekty funkcjonowania wspólnoty Anonimowych Alkoholików, przydatne w oddziaływaniach resocjalizacyjnych w zakładach karnych i aresztach śledczych. Przegląd Więziennictwa Polskiego. Warszawa: 2017; 96: 87-102.

34. Doktor Bob i dobrzy weterani. Fundacja Biuro Służby Krajowe Anonimowych Alkoholików w Polsce. Warszawa 2015: 251.

35. Anonimowi Alkoholicy, Fundacja Służby Krajowej Anonimowych Alkoholików w Polsce. Warszawa 2000: 91-119.

36. Praca grup Al-Anon i Alateen, (wyd. III); Stowarzyszenie Służb Grup Rodzinnych Al-Anon. Poznań: 2008: 4-5.

37. Praca grup Al-Anon i Alateen, (wyd. III); Stowarzyszenie Służb Grup Rodzinnych Al-Anon. Poznań: 2008: 17-19.

38. Grupa AA. Gdzie wszystko się zaczyna. Jak funkcjonuje grupa. Jak zacząć. red. Służby Światowe Anonimowych Alkoholików. Fundacja Biuro Służby Krajowej Anonimowych Alkoholików w Polsce. Warszawa: 2015: 15.

39. Praca grup Al-Anon i Alateen (wyd. III). Stowarzyszenie Służb Grup Rodzinnych Al-Anon. Poznań: 2008: 56-58.

40. http://aa.org.pl/konferencje/sk_karta_zal2_2011.pdf [dostęp: 23.04.2019 r.].

41. http://al-anon.org.pl/wp-content/uploads/2018/01/informator-nr-4-15-2016.pdf s. 23 [dostęp: 23.04.2019 r.].

42. Humpreys $\mathrm{K}$ i inni. Estimating the efficacy of Alcoholics Anonymous without self-selection bias: An instrumental variables re-analysis of randomized clinical trials. Alcohol Clin Exp Res. 2014; 38(11): 2688-2694.

43. Kaskutas LA. Alcoholics Anonymous Effectiveness: Faith Meets Science. J Addiction Dis. 2009; 28(2): 145-147.

44. Kelly JF i inni. Can 12 Step Group participation strengthen and extend the benefits of adolescent addiction treatment? Drug Alcohol Dependence. 2010; 110(1-2): 117-125.

45. Pagano ME $\mathrm{i}$ inni. Helping other alcoholics in alcoholics anonymous and drinking outcomes: findings from project MATCH. J Stud Alcohol. 2004; 65(6): 766-773.

46. Timko C i inni. Al-Anon Family Groups: Newcomers and Members. J Stud Alcohol Drugs. 2013; 74(6): 965-976.

47. Timko $\mathrm{C}$ i inni. Social Processes Explaining the Benefits of Al-Anon Participation. Psychol Addict Behav. 2015; 29(4): 856-863. 
48. Timko C i inni. Newcomers to Al-Anon Family Groups. Who stays and who drops out? Addictive Behaviours. 2014; 39(6): 1042-1049.

49. Kelly $\mathrm{J}$ i inni. Do drug-dependent patients attending Alcohol Anonymous rather than Narcotic Anonymous do as well? A prospective Lagged, matching Analysis. Alcohol and Alcoholism. 2014; 49(6): 645-653.

50. Kelly JF. Is Alcoholics Anonymous religious, spiritual, neither? Findings from 25 years of mechanisms of behavior change research. Addiction. 2017; 112(6): 929-936.

51. Schuler A i inni. Gamblers Anonymous as a Recovery Pathway: A scoping review. J Gambl Stud. 2016; 32(4): 1261-1278.

52. Efrati Y, Gola M. Compulsive sexual behavior: A twelve-step therapeutic approach. J Behav Addiction. 2018; 1; 7(2): 445-453.

53. Praca Grup Al-Anon i Alateen (wyd. III). Stowarzyszenie Służb Grup Rodzinnych Al-Anon. Poznań 2008: 5.

54. http://www.parpa.pl/images/file/srodek_popr4.pdf [dostęp; 23.04.2019 r.]
Artykuł przyjęty do redakcji: 07.05.2019.

Artykuł przyjęty do publikacji: 23.07.2019.

Źródło finansowania: Praca nie jest finansowana z żadnego źródła. Konflikt interesów: Autorzy deklarują brak konfliktu interesów.

\section{Adres do korespondencji:}

Łukasz Kołodziej

ul. Batalionów Chłopskich 6/51

33-300 Nowy Sącz

tel. 510481694

e-mail: lukasz.kl@interia.pl

Fundacja Instytut Zdrowia FIZ-LK, Prywatny Ośrodek Terapii Uzależnień TRATWA 